\title{
Analysis of Solar-Assisted Cooling Chamber
}

\author{
Mustafa Atmaca, Ahmet Berk Kurtulus, Ibrahim Girgin, and Cuneyt Ezgi
}

\begin{abstract}
In this study, prototype product cooling chamber which has $1 \mathrm{~m}^{3}$ volume have been designed. This cooling chamber is suitable Eurovent SC2 conditions and works between $0^{\circ} \mathrm{C}$ and $+4^{\circ} \mathrm{C}$. The system was run with electricity obtained by means of photovoltaic solar panels. Comparison of efficiency was made between cities of Istanbul and Mersin which are different annual solar radiation values. Photovoltaic systems do not have any moving equipment, so the longest life provide with minimal maintenance. In addition, these systems don't produce greenhouse gases or other types of gas. Therefore using of this energy will reduce greenhouse gas emissions and will decrease electricity costs for the country and the world.
\end{abstract}

Index Terms - Solar energy, cooling, photovoltaic panel.

\section{INTRODUCTION}

A lot of activities have been implemented in the 80 s of the last century on the development of solar energy systems for air conditioning application, especially in the United States and Japan. Although significant progress has been provided in the development of components and systems, economic reasons blocked further progress. Lately, several new activities in this field have started and both research and demonstration projects are implemented in many countries and also in international co-operative projects for instance in the framework of the Solar Heating and Cooling Programme of the International Energy Agency (IEA). Especially the development of the market of high efficient solar thermal collectors, which are nowadays produced on an semi-industrial or industrial level, provides a good starting point for new attempts [1].

Today, the fast development of countries around the world and to reach results in the world of modern energy sources is increasing by the day that is needed in energy costs in general. That's why energy plays a strategic role in our age. Electricity amount spent for cooling and ventilation in many countries includes a large proportion of the total electricity consumption. Approximately $80 \%$ of the electricity produced in the world is obtained by burning fossil fuels [2] 21st century. Since the beginning of the world, average temperature has increased $0.6 \mathrm{~K}$. Also held in 2001, "Climate Change" panel warning made by the average temperature is projected to the year 2100 will increase from 1.5 to $4.5 \mathrm{~K}$ [3]. Global warming is serious enough to have entered the country and people into equalized aim to prevent this situation a step. Only one of them, and their emissions of

Manuscript received November 17, 2015; revised Feburary 17, 2016.

Mustafa Atmaca and Ahmet Berk Kurtulus are with the Faculty of Technology, Mechanical Engineering Department, Marmara, University of Kadıkoy, Istanbul, 34722 Turkey (e-mail: matmataca@marmara.edu.tr, berk.kurtulus@marmara.edu.tr).

İbrahim Girgin and Cüneyt Ezgi are with the Department of Mechanical Engineering at Turkish Naval Academy, 34942 Tuzla, İstanbul, Turkey (e-mail: igirgin@dho.edu.tr, cezgi@dho.edu.tr). developed industrial countries through the signing of the Kyoto Protocol in 1992 and 5.2\% drop had been stipulated [4].

Energy costs of cold rooms mean because it is good better producing only the initial investment costs meet their energy and leave a cleaner world for both companies working rooms with this energy will be reduced and the greenhouse gas emissions of the electricity costs for the country and the world.

\section{IMPORTANT OF SOLAR ENERGY}

Providing the suitable comfort conditions for cooling and air conditioning goal in summer season is one of the main forthcoming utilizations of solar energy especially in regions, which enjoy with reasonable higher rates of solar intensity on a long period of the year [5]. A lot of solar assisted AC and cooling systems have been established in different countries for residential buildings, and the researches are continuing to reach economical and efficient thermal systems if they compared with conventional systems [6], [7].

The potential use of solar energy in our country is more than all European countries except Spain. Turkey, an average $1311 \mathrm{kWh} / \mathrm{m}^{2}$ year has the potential to benefit from solar energy. This rate is more than 10,000 times the electricity and fossil energy resources consumed in our country [8].

The second comes from the Sun approximately 170 million MW of energy worldwide. Turkey's annual energy production of 100 million MW of solar energy to the world that if a second thought, Turkey's energy production is 1700 times. State Meteorology Affairs General Directorate (DMI), sunshine duration and radiation intensity when measured from 1966 to 1982 year, according to a study conducted by EIE benefiting from the data average annual sunshine duration of the Turkey 2640 hours (total daily 7.2 hours), average total radiation intensity $1311 \mathrm{kWh} / \mathrm{m}^{2}$-year (total daily $3.6 \mathrm{kWh} / \mathrm{m}^{2}$ ) was determined to be. Turkey has a high solar energy potential, such as 110 days, and if the necessary investment in Turkey can produce an average of $1100 \mathrm{kWh}$ of solar energy per square meter per year [9]-[11].

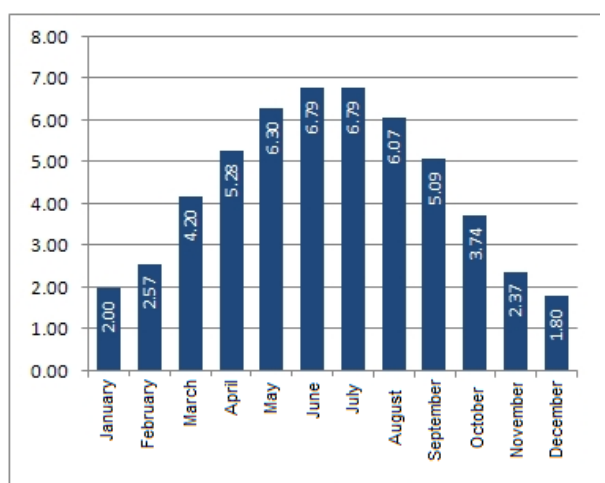

Fig. 1. Istanbul global radiation values $\left(\mathrm{kWh} / \mathrm{m}^{2}\right.$-day). 


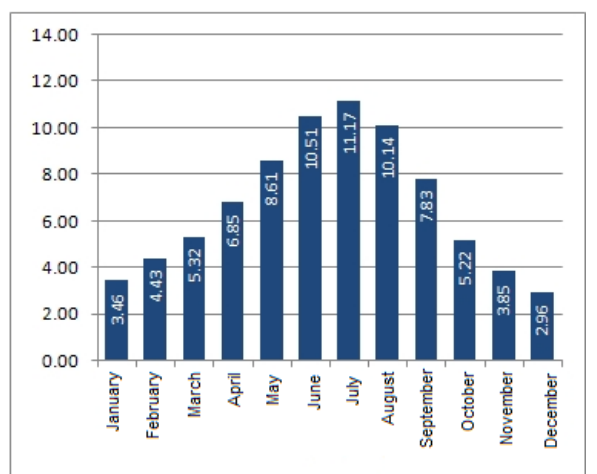

Fig. 2. Istanbul sunny times yearly (hour).

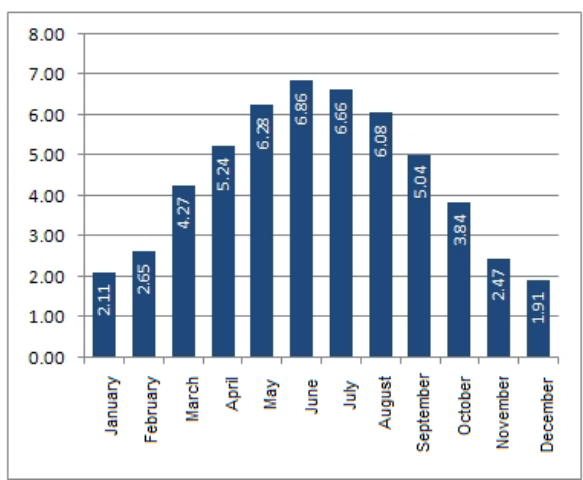

Fig. 3. Mersin global radiation values $\left(\mathrm{kWh} / \mathrm{m}^{2}\right.$-day).

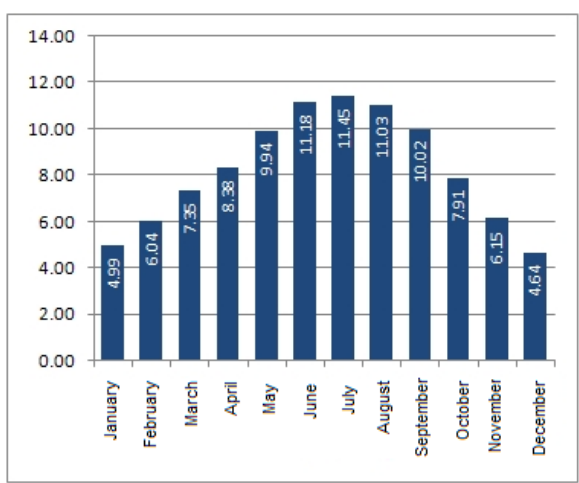

Fig. 4. Mersin sunny times yearly (hour).

Istanbul and Mersin Global Radiation values and Sunny Times are given in Fig. 1-Fig. 4 respectively [12], [13]. However, these values, Turkey was less than the true potential was then determined by the studies. Since 1992, IRA and DMI, the value of solar energy for solar energy are taking measures in order to measure more healthy.

As a result of the measurement work in progress, of the solar energy potential in Turkey it is expected to increase by $20-25 \%$ compared to the old value today and in the near future [14].

\section{SOLAR SYSTEMS}

Because of high energy costs, using renewable energy sources in heating and cooling systems has become important Solar cooling applications have increased rapidly in Europe in recent years [15].

In order to pull dawn primary energy consumption and diminish negative environmental influences, solar-assisted air-conditioning and space-heating systems are becoming more foremost day after day. Solar space-heating and air-conditioning are especially appealing, since cooling and heating loads and availability of solar radiation are generally in phase, particularly in commercial buildings where night air-conditioning ore space heating are not required [16].

In mechanical vapor compression refrigeration, compressor works with DC motors instead of AC motors by activating the system. This is the only difference from mechanical vapor compression cycle. DC motor power is provided through photovoltaic panel (PV). Efficiency of these panels reach $15-17 \%$; but the average yields of the PV panels seen as common in the market are around $10.3 \%$. COP (Coefficient of Performance) values of these systems ranged between 1.1 and 3.3 and reached very high values compared to other solar driven cooling system. Considering to the carbon footprint of PV panel, due to the high amount of electricity used in the production, there are highly greenhouse gas emissions [17].

Solar cells, but still had no electricity network, remote locations can be used in accordance with the economic aspect of the settlement. For this reason, and because they can usually set up in the desired signal power, etc. to meet the needs of rural electricity. As it used in the application. In our country telecom stations, General Directorate of Forestry fire lookout stations, lighthouses and highway lighting used in solar batteries installed capacity of $300 \mathrm{~kW}$. Methods to be applied in our country in terms of electricity production, although not a problem in terms of the use of solar energy resources are some regional differences. Photovoltaic systems with cloudy or clear all kinds of weather conditions that electricity be produced in concentrator systems (thermal and mechanical conversion) direct radiation, so outdoor air is required. Therefore, thermal and mechanical alternating generators that should be preferred in the Southeast Anatolia and the Mediterranean regions, all regions except Eastern Black Sea region is suitable for photovoltaic generators [18].

\section{A. Istanbul and Mersin}

In this study, prototype product cooling chamber which has $1 \mathrm{~m}^{3}$ volume have been designed. This cooling chamber is suitable Eurovent $\mathrm{SC}_{2}$ conditions and works between $0{ }^{\circ} \mathrm{C}$ and $+4^{\circ} \mathrm{C}$. System has been started electricity obtained by means of photovoltaic solar panel. Thus, Istanbul and Mersin which is different values of annual solar radiation and latitude have been compared in terms of efficiency.

These comparison results have been determined which provinces have more advantageous in the installation of the system.

Theoretical and experimental comparisons of results for Istanbul and theoretical comparison of results for Mersin are carried out. Room temperatures for apple (golden) and pomegranate have been adjusted with digital thermometer.

For storing these fruit in cold room, suitable conditions have been created. The aim of this prototype is to provide clean energy by fulfilling the needs of the solar cooling chamber for a cleaner world.

The storage conditions of fruits are given in Table I. (Ozkol, 2007).

TABLE I: PRODUCT FEATURES

\begin{tabular}{lcccc}
\hline \hline \multirow{2}{*}{ City } & $\begin{array}{c}\text { Casing } \\
\text { Temp. } \\
\left({ }^{\circ} \mathrm{C}\right)\end{array}$ & $\begin{array}{c}\text { Room } \\
\text { Humidity } \\
\left({ }^{\circ} \mathrm{C}\right)\end{array}$ & $\begin{array}{c}\text { Freezing } \\
\text { Temp. } \\
\left({ }^{\circ} \mathrm{C}\right)\end{array}$ & $\begin{array}{c}\text { Cooling } \\
\text { Temp. } \\
\left({ }^{\circ} \mathrm{C}\right)\end{array}$ \\
\hline Pomegranate & 0 & 90 & $-3,0$ & 0,86 \\
\hline Apple (Golden $)$ & 4 & 90 & $-1,1$ & 0,88 \\
\hline
\end{tabular}


Differences compared to other systems of this project in terms of cooling chamber, electrical energy obtained from photovoltaic solar panel is transferred to the system reducing the dependence on network. In addition, the effect of operating efficiency f cooling system has been investigated of solar radiation values of prototype system which was established in Istanbul and solar radiation values which Mersin receives theoretically.

Some assumptions were made in order to put into operation the prototype of the study. For this purpose the cooling room was created. The ambient temperature values used for heat gain calculation are given in Table II for Istanbul and Mersin [19].

TABLE II: CiTIES FEATURES

\begin{tabular}{lccccc}
\hline \hline City & $\begin{array}{c}\text { Winter } \\
\text { Temp. } \\
\left({ }^{\circ} \mathrm{C}\right)\end{array}$ & $\begin{array}{c}\text { Sum. Dry } \\
\text { Temp. }\left({ }^{\circ} \mathrm{C}\right)\end{array}$ & $\begin{array}{c}\text { Sum. Wet } \\
\text { Temp. } \\
\left({ }^{\circ} \mathrm{C}\right)\end{array}$ & Latit. & Longit. \\
\hline Ist. & -3 & 33 & 24 & 28 & 41 \\
\hline Mer. & +3 & 35 & 29 & 34 & 36 \\
\hline
\end{tabular}

- Isolation heat transfer coefficient, $\lambda=0.035 \mathrm{Kcal} / \mathrm{h}{ }^{\circ} \mathrm{Cm}^{2} / \mathrm{m}$ has been assumed. (styrofor, cork, glass wool, etc.)

- Daily working time is taken 16 hours.

- The outside ambient temperature of $35^{\circ} \mathrm{C}$ was adopted.

- Adopted rooms close to each other with most of that length.

\section{B. Experimental Setup}

Cooling processes have applied in cold storage facilities commonly. These systems run according to the vapor compression refrigeration cycle as a conventional method. In this system, it is seen in Fig. 5, compressor which makes compression work operates with electric power.

Although there is no environmental pollutant effect of electricity, fossil-based energy sources using for electricity production has a very polluting effect. Because of the origin of the electricity used, cold storage cause pollution of the environment even indirectly [20].

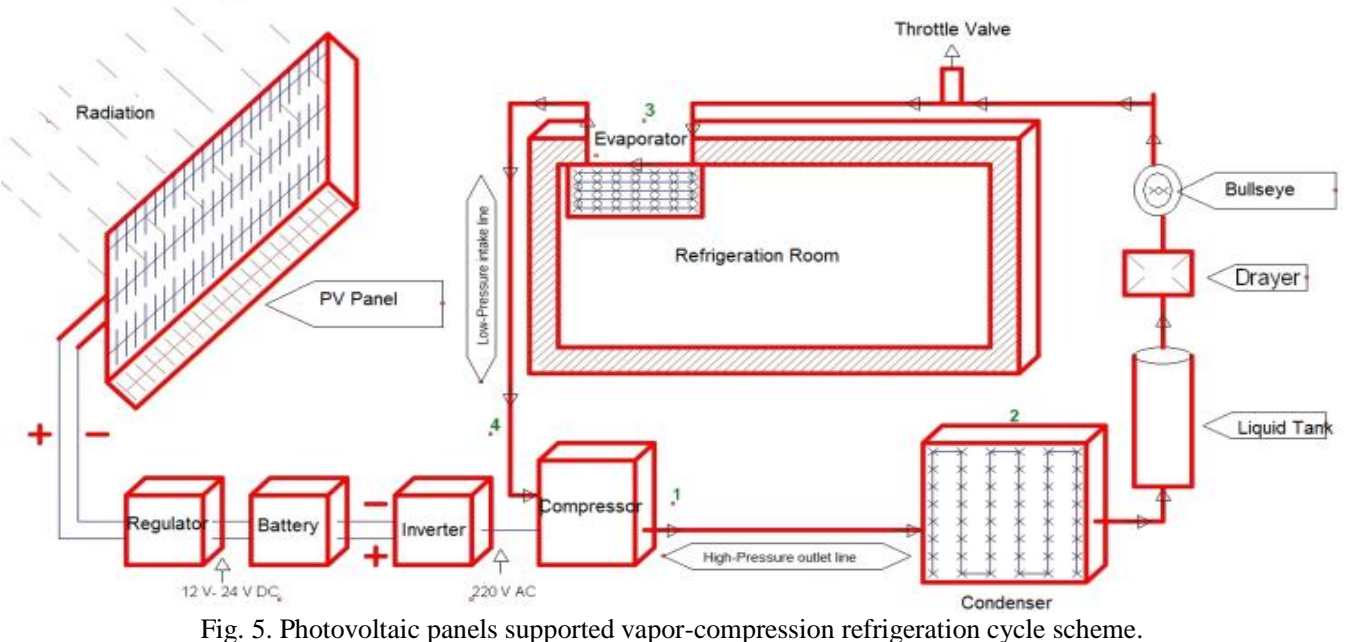

Size of the room will be a prototype for vapor-compression refrigeration volume has been determined as of $1 \mathrm{~m}^{3} .1 \mathrm{~m}^{3}$ of room to hide in the volume of fruit such as apples (golden) and was the pomegranate. At $0^{\circ} \mathrm{C}$ for apple, evaporation temperature of $4^{\circ} \mathrm{C}$ storage conditions to ensure Pomegranate $-10{ }^{\circ} \mathrm{C}$ to $300 \mathrm{~W}$ capacity compressor that Wansheng QD $52 \mathrm{H}$ model selected. When this compressor will operate in accordance with theoretical calculations $\mathrm{SC}_{2}$ conditions condenser $650 \mathrm{~W}, 350 \mathrm{~W}$, it was determined that the evaporator capacity is needed. R134a as refrigerant fluid that circulates in the system was determined 1 liter fluid capacity fluid storage tank to use and efficient. $20 \mathrm{~g}$ of this fluid in order to continually filter drier filter, sight glass also needs to see the fluid gas-liquid state to pass through the copper tubing set.

The cold room size suitable advantage will be provided polyurethane panels will be installed in $100 \mathrm{~mm}$ of $1 \mathrm{~m}^{3}$ room. The cooling system is estimated to be of the electricity needs of $275 \mathrm{~W}$ solar panel so the capacity of the mind would be lost in the solar collector was chosen as 300 Watts. $15 \mathrm{~A}$ regulator in accordance with the system for charging gel batteries properly according to information from the company that sells renewable energy products have been selected. To be used in cases where the sun of solar collectors

take about 6 hours to ensure the continuity of the cooling system $12 \mathrm{~V} 100$ Ah gel battery is selected. Gel batteries from a $12 \mathrm{~V}$ DC power to the cooling system can be used as $220 \mathrm{~V}-\mathrm{AC}$ (recycling) and $275 \mathrm{~W}$ of power in order to meet the needs planned to use 300 watts Pure Sine Wave Inverter.

Wheeled table will be provided for the prototype to be installed. This table will be set up in the part of determining the cold room and cold room evaporators will be mounted on the ceiling. If the rest of the table will be placed outside the cold room on the remaining elements of the cooling system. To take advantage of solar energy, photovoltaic solar panels, AC-DC inverter, solar battery components such as regulators and will be provided. The remaining empty space photovoltaic solar panels will be installed on the cold room. Solar battery, a DC-AC inverter and controller will be placed on a trolley table.

\section{Cooling Calculations}

We may collect heat gain occurring cooling load in the four main groups:

- Heat of transmission from walls, floor and ceiling

- Heat of infiltration

- heat from the product

- Heat from heat sources (lighting, motors, defrosting) 
It is seen component of cooling room details in Table III.

\begin{tabular}{|c|c|c|c|}
\hline Component & \multicolumn{2}{|c|}{$\begin{array}{c}\text { Thickness } \\
{[\mathrm{mm}]}\end{array}$} & $\begin{array}{c}\text { Heat } \\
\text { Cond.Coeff. } \\
{[\mathrm{W} / \mathrm{mK}]}\end{array}$ \\
\hline $\begin{array}{l}\text { Galvaneiz } \\
\text { Wall }\end{array}$ & $\begin{array}{c}\text { Inside } \\
0.55\end{array}$ & $\begin{array}{c}\text { Outside } \\
0.45\end{array}$ & 16 \\
\hline $\begin{array}{l}\text { Polyurethane } \\
\text { Wall }\end{array}$ & \multicolumn{2}{|c|}{90} & 0.0024 \\
\hline $\begin{array}{l}\text { Galvaneiz } \\
\text { Door }\end{array}$ & $\begin{array}{c}\text { Inside } \\
0.5\end{array}$ & $\begin{array}{c}\text { Outside } \\
0.5\end{array}$ & 16 \\
\hline $\begin{array}{l}\text { Polyurethane } \\
\text { Door }\end{array}$ & \multicolumn{2}{|c|}{39} & 0.0024 \\
\hline
\end{tabular}

It is given results of transmission heat below in Table IV.

TABLE IV: CITIES COOLING CONDITIONS

\begin{tabular}{|c|c|c|c|c|c|}
\hline City & $\begin{array}{c}\text { Side-Tot } \\
\text { Heat Tra. } \\
\text { Coeff. } \\
{\left[\mathrm{W} / \mathrm{m}^{2} \mathrm{~K}\right]}\end{array}$ & $\begin{array}{c}\text { Side Heat } \\
\text { Tra. [W] }\end{array}$ & $\begin{array}{c}\text { Door- Tot. } \\
\text { Heat Tra. } \\
\text { Coeff. } \\
{\left[\mathrm{W} / \mathrm{m}^{2} \mathrm{~K}\right]}\end{array}$ & $\begin{array}{c}\text { Door } \\
\text { Heat } \\
\text { Tra. [W] }\end{array}$ & $\begin{array}{c}\text { Total } \\
\text { Heat Tra. } \\
{[\mathrm{W}]}\end{array}$ \\
\hline Ist. & 0.251 & 8.283 & 0.54 & 10.87 & 52.28 \\
\hline Mersin & 0.251 & 8.785 & 0.54 & 5.12 & 55.45 \\
\hline
\end{tabular}

Cooling room is constituting a part of the load to be underestimated and the infiltration heat which is calculated as given in equation 1 can be reduced by being slow down external air into the cold room. For this purpose, air curtain entrance to the room, the front entrance hall, the door opens and closes automatically as measures are being taken to put [21].

$$
\begin{gathered}
Q_{\mathrm{inf}}=0.05525 g A H F_{m} \rho_{r}\left(h_{i}-h_{r}\right)\left(1-\rho_{i} / \rho_{r}\right) \\
\times\left[D_{f} D_{t}\left(1-E_{f}\right)\right]
\end{gathered}
$$

It is determined inside cooling room in $0{ }^{\circ} \mathrm{C}$, relative humidity $90 \%$ and outside temperature $33^{\circ} \mathrm{C}$ and relative humidity $50 \%$ by Daikin-Psychometry Diagram-Turkish V2.1.0.

The transmission heat is obtained for the apple $120 \mathrm{~W}$ and pomegranate $136 \mathrm{~W}$.

In cooling room put various types of products are stored heat caused from time to time constitute the most important and largest part of the cooling load. In addition, cooling room could be vary according to the type of goods put the needs and aspirations of the amount of movement when using the unit even though it may be predetermined.

Therefore, the load calculation of cooling room and choosing devices accordingly by making goods moving in harmony as close as possible to the practical situation is of great importance. In case of extreme shape and the application of the goods movement to be much more as unnecessarily will lead to the use of selected high-capacity cold room equipment, and the real situation will be caused than the lower receipt by the inadequate cooling room equipments. In cooling room for apples or pomegranate products will be approximately $75 \mathrm{~kg}$ of product to be stored is $20 \%$ in $1 \mathrm{~m} 2$ area of the rooms which it has been done considering that the process left blank. Cooling load is calculated as the value in equation (2).

$$
Q=m c \Delta T
$$

It is obtained cooling heat for apple $22.14 \mathrm{~W}$ and for pomegranate $21.63 \mathrm{~W}$.

Inside of cooling room is $0.7 \mathrm{~A}$ electricrity and $1 \mathrm{~m}$ length using led. Lighting heat is given below;

$$
\begin{gathered}
Q_{\text {light }}=I \times V \\
Q_{\text {light }}=0.7 \times 12 \\
Q_{\text {light }}=8.4 \mathrm{~W}
\end{gathered}
$$

Electric motors, according to the type of electric motor power and power factor changes, return power to heat ratio will be changed. In addition, it converts the energy of the electric motor is used to power cooled volume in space while staying in this case mean all the energy in a room.

By the evaporator on the ceiling of the cooling room temperature is calculated as given in equation 3 below [22].

$$
Q_{\text {evp }}=2545 \times P \times \mathrm{FUM} \times \mathrm{FLM}
$$

where $P$ is the power of the electric motor, the FIM, motor utilization factor and load factor represents the FLM engine. The power of system we use in the evaporator were $0.02 \mathrm{hp}$ electric motor and daily for $\mathrm{FUM}=1$ and $\mathrm{FLM}=1$ and it is obtained evaporator heat capacity $14.7 \mathrm{~W}$.

It is obtained as result of Toplam 1s1 kazanc1 (Qtotal) aşağıdaki gibi hesaplanmıştır.

$$
Q_{\text {total }}=Q_{\text {trans }}+Q_{\text {inf }}+Q_{\text {product }}+Q_{\text {light }}+Q_{\text {fan }}
$$

As a result of theoretical calculations are done in the project; Total total cooling load for Istanbul and Mersin $236.69 \mathrm{~W} 216.25 \mathrm{~W}$ are obtained. Capacity of the mechanical vapor compression cooling system component values are calculated based on the city of Mersin.

The thermal coefficient of performance, COP is defined as the useful cold, $Q_{\text {cold }}$, per unit of invested driving heat, $Q_{\text {heat }}$

$$
\mathrm{COP}=Q_{\text {cold }} / Q_{\text {heat }}
$$

Refrigeration cycle and pressure-enthalpy change are showed in Fig. 6 and Fig. 7.

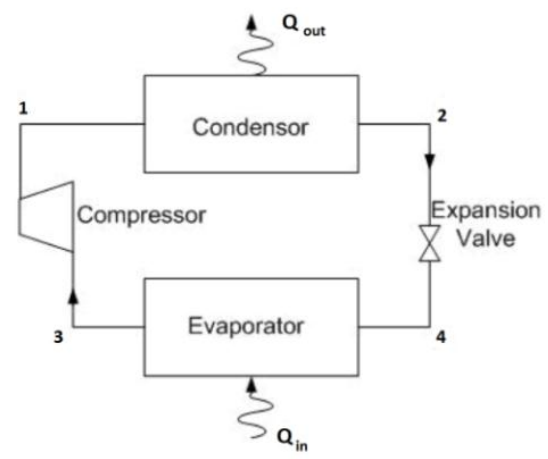

Fig. 6. Refrigeration cycle.

\section{Evaporator Selection}

Evaporator Temperature $=-4^{\circ} \mathrm{C}$

Condenser Temperaure $=+50^{\circ} \mathrm{C}$

From $\ln \mathrm{P}-\mathrm{h}$ diagram for $\mathrm{R}-134 \mathrm{a}$, enthalpy values is read as follow:

$$
h_{2}=h_{3}=271.6 \mathrm{~kJ} / \mathrm{kg}
$$




$$
\begin{aligned}
& h_{4}=396.2 \mathrm{~kJ} / \mathrm{kg} \\
& h_{1}=423.4 \mathrm{~kJ} / \mathrm{kg} \\
& Q_{\text {evap }}>Q_{\text {cold }} \\
& Q_{\text {evap }}=350 \mathrm{~W}=1260 \mathrm{~kJ} / \mathrm{h}
\end{aligned}
$$

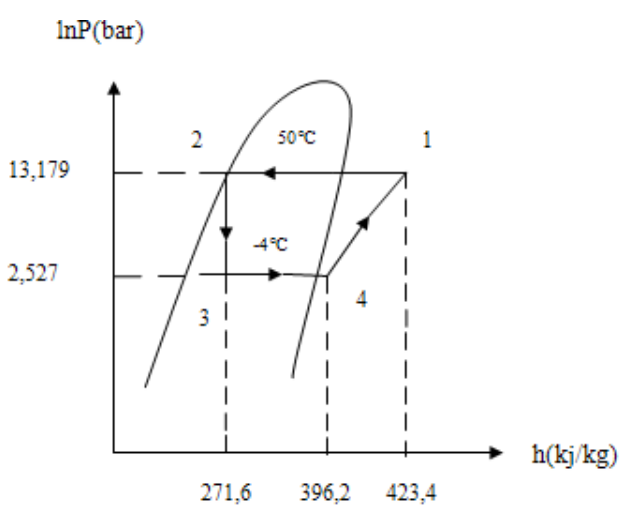

Fig. 7. Pressure-enthalpy diagram for R-134a.

In prototip study, evaporator with a capacity of $600 \mathrm{~W}$ was used.

$$
Q_{\text {evap }}=m_{\mathrm{R} 134 \mathrm{a}} \times\left(h_{4}-h_{3}\right)
$$

where $m_{\mathrm{R} 134 \mathrm{a}}=10.112 \mathrm{~kg} / \mathrm{h}$

Condenser Selection

$$
Q_{\text {cond }}=m_{\mathrm{R} 134 \mathrm{a}} \times\left(h_{1}-h_{2}\right)
$$

where $Q_{\text {cond }}=1535 \mathrm{~kJ} / \mathrm{h}=426.388 \mathrm{~W}$

In prototip study, condenser with a capacity of $1.5 \mathrm{~kW}$ was used.

Compressor Selection

$$
Q_{\text {comp }}=m_{\mathrm{R} 134 \mathrm{a}} \times\left(h_{1}-h_{2}\right)
$$

where $Q_{\text {comp }}=275 \mathrm{~kJ} / \mathrm{h}=76.388 \mathrm{~W}$

In prototip study, compressor which nominal power is 270W was used.

The following materials are selected as solar products.

- 250W Policristal Solar Panel

- $2 \times 50$ Ah Jel battery

- 15 A Solar Regulator

- 3000 W Modified Sinus inverter

Coefficient of Performance (COP)

In theoretical study, COP is found as follow for Istanbul and Mersin;

$$
\begin{aligned}
\mathrm{COP}_{\text {Istanbul }} & =\frac{216,25}{76,388}=2.83 \\
\mathrm{COP}_{\text {Mersin }} & =\frac{236.69}{76,388}=3.1
\end{aligned}
$$

In Prototip study, COP is found as follow in Istanbul

$$
\mathrm{COP}_{\text {Istanbul }}=\frac{600}{270}=2.22
$$

When it was compared according to cooling load, Mersin can be seen disadvantaged but it should be considered together profits from solar energy. According to this, the establishment of this system would be more appropriate for Mersin.

\section{CONCLUSION}

It won the seriousness of global warming, which increasingly more expensive fossil fuels and decreases on the other hand the combustion of fossil fuels consists of both environmental pollution as well as the increase of greenhouse gases emitted into the atmosphere and cause global warming. $\mathrm{CO}_{2}$ excess of the global average temperature over the last century caused an estimated 0.5 degree rise. In order to reduce $\mathrm{CO}_{2}$ emissions due to the greenhouse effect is seen as primarily responsible for global warming is needed is a growing interest in renewable energy sources worldwide. Renewable energy, fossil fuels as they do not adversely affect the environment, they are faced with resource depletion problem, and will never in the future by creating a sustainable system that is very important to provide the opportunity to live their quality.

These facts we need from renewable and clean energy in the light is extremely clear. To meet the very high levels, especially in summer, and the resulting need to use at least the cooling system of renewable energy sources as support obligation has arisen. The planned solar-assisted vapor-compression refrigeration prototype that shows the shortcomings in our country thanks to the use of renewable energy sources draw attention to this issue and would be of great importance to reveal new studies are being considered.

As a control element in the system is used two digital thermostats, which are the condenser and the evaporator fans are controlled operating range. In addition, the room temperature is between $0-4{ }^{\circ} \mathrm{C}$, compressor can be stopped by thermostat control. When the critical temperature of the cooling room thermostat set later, the compressor starts to work again. With this application the energy savings can be achieved.

In this study, inverter, solar regulator, digital thermostat and connections package switches are taken into electrical panel. Thus it is provided to protect the electrical components against external influences. Electrical energy which will activate the system; via switch means both the mains power can be supplied from solar energy. The internal temperature of the room inside do in the measurements at from $23^{\circ} \mathrm{C}$ to $4^{\circ} \mathrm{C}$ was found to be reduced approximately 60 minutes.

As results of theoretical calculations are done in the project; Total cooling load for Istanbul and Mersin 236.69W and $216.25 \mathrm{~W}$ are determined. Capacity of the mechanical vapor compression cooling system component values are calculated based on the city of Mersin.

When Istanbul annual sunshine duration (time) and Mersin annual sunshine duration (time) are compared, the average annual sunshine duration of Mersin, hence in Mersin energy of the solar system that brings more efficiency. Mersin and Istanbul are compared to cooling load is also possible disadvantage observed in Mersin when considered in conjunction with the gains derived from solar energy would be more appropriate functioning of the establishment of this system.

Photovoltaic cells are induced high initial production and consumption costs; however, there are becoming more 
widespread, with technological advances and declines in energy costs. With the expansion of the use of cost it is expected to be further reduced. Because solar energy is intermittent energy source its storage facilities are limited. The disadvantages of the solar energy system are maintenance and life of the storage unit. Thus, efficiency of the system decrease and increase the cost of solar energy.

\section{NOMENCLATURE}

$h_{i}:$ Air enthalpy from door
$h_{r}:$ Door enthalpy
$\rho_{r}:$ Colling room density
$\rho_{i}:$ From outside density
$g:$ Gravitation
$A:$ Door area
$H:$ Door height
$F_{m}:$ Density factor
$D_{f}:$ Door flow factor
$D_{t}:$ Hourly opened door
$E_{f}:$ Efficiency strip door
$c_{e}=3,643 \mathrm{kj} / \mathrm{kg}^{\circ} \mathrm{C}$ for apple
$c_{n}=3,559 \mathrm{kj} / \mathrm{kg}^{\circ} \mathrm{C}$ for pomegranate
$Q_{\text {trans }}:$ Transmission heat
$Q_{\text {inf }}:$ Infiltration heat
$Q_{\text {light }}:$ Lighting heat
$Q_{\text {fan }}:$ Fan energy
$Q_{t \text { talal }}:$ Total heat energy

\section{ACKNOWLEDGMENT}

The research has been supported by the Marmara University Scientific Research Commission in Istanbul through the project No. FEN-D.130116-0015

\section{REFERENCES}

[1] H.-M. Henning, "Solar assisted air conditioning of buildings — an overview," Applied Thermal Engineering, vol. 27, pp. 1734-1749, 2007.

[2] K. F. Fong, T. T. Chow, C. K. Lee, Z. Lin, and L. S. Chan, "Comparative study of different solar cooling system," Solar Energy, 2010.

[3] UN Intergovernmental Panel on Climate Change (IPCC), 2001.

[4] D. S. Kim and C. A. Ferreira, "Solar refrigeration options - a stateof-the-art review," Int. J. of Ref., vol. 31, pp. 3-15, 2008.

[5] H.-M. Henning, "Solar assisted air conditioning of buildings — an overview," Applied Thermal Engineering, vol. 27, pp. 1734-1749, 2007.

[6] M. A. Sayegh, "The solar contribution to air conditioning systems for residential buildings," Desalination, vol. 209, pp. 171-176, 2007.

[7] H.-M. Henning, "Solar assisted air conditioning of buildings," 2000.

[8] J. R. Williams, Design an Installation of Solar Heating and Hot Water System, Ann Arbor Publishers, 1984.

[9] S. Goktun and I. D. Er, "The optimum performance of a solar-assisted combined absorption - vapor compression system for air conditioning and space heating," Solar Energy, vol. 71, no. 3, pp. 213-216, 2001.

[10] S. Schicho, "Amorphous and microcrystalline silicon applied in very thin tandem solar cells," Jülich Forschungzentrum, 2011.

[11] Survey administration of electrical works. (2012). [Online]. Available: www.eie.gov.tr

[12] Survey administration of electrical works. (2012). [Online]. Available: www.eie.gov.tr/ MyCalculator/pages/34.asp

[13] Survey administration of electrical works. (2012). [Online]. Available: www.eie.gov.tr/ MyCalculator/pages/33.asp
[14] T. Tsoutsos, "Environmental impacts from the solar energy technologies," Energy Policy, vol. 33, pp. 289-296, 2005.

[15] C. Onan and D. B. Ozkan, "Gunes enerjisi destekli sogutma sistemleri ve ornek projenin diger uygulamalarla karsilastirilmasi," Tesisat Muhendisligi, pp. 11-18, 2009.

[16] Turkey Environmental Foundation, Turkey's Environmental Problems, Ankara, 2003.

[17] K. Sevinc and A. Gungor, "Solar cooling systems and new applications," Muhendis ve Makina, vol. 53, pp. 59-70, 2012.

[18] Survey administration of electrical works. (2015). [Online]. Available: www.eie.gov.tr/eie-web/ turkce/YEK/gunes/tgunes.html

[19] N. Ozkol, "Uygulamali Sogutma Teknigi," MMO yayın, no. 115, 2007.

[20] Ucgul and Ibrahim, "Thermodynamic, environmental and economic analyses of solar ejector refrigeration system application for cold storage," Pamukkale Üniversitesi Muhendislik Bilimleri Dergisi, vol. 15 , no. 2, pp. 269-277, 2009.

[21] ASHRAE Handbook, 2010.

[22] Bhatia. (2012). A. overview of vapor absorption cooling systems. [Online]. Available: http://www.cedengineering.com/upload/Vapor\%20Absorption\%20Ma chines.pdf

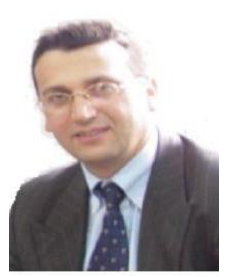

Mustafa Atmaca was graduated in 1993 from Yildiz Technical University, the Faculty of Mechanical Engineering. In 1994, he joined Marmara University, Faculty of Technical Education as a research assistant in the Department of Mechanical and his academic life was started. He completed the master's degree in 1996 and the doctorate degree in 2003. In 2010, he became an associate professor still with Marmara University, Faculty of Technology, Department of Mechanica Engineering. He is a member of Chamber of Mechanical Engineers. His main research areas are wind tunnel testing and optimization, exergy, HVAC systems, energy efficiency in building.

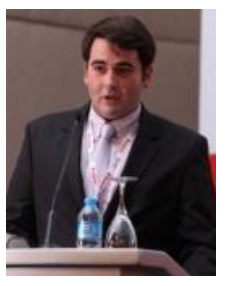

Ahmet Berk Kurtulus was born in Istanbul in 1988. In 2010, he was graduated from the Department of Mechanical Engineering, Faculty of Engineering, Sakarya University. Then he went to Istanbul Technical University Institute of Science, Department of Mechanical Engineering of Thermal-Fluid Program for his graduate study in 2011. In the same year, he joined Marmara University, Faculty of Technology, the Department of Mechanical Engineering as a research assistant. Currently, he continues his graduate education and research assistantship. His main research areas include two-phase flows, transfer mechanisms in Porous media, exergy and energy efficiency in buildings. He is a member of ASHRAE, Chamber of Mechanical Engineers and the Turkish Heat Science and Technique Association.

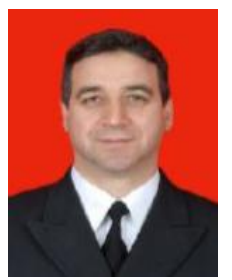

Ibrahim Girgin is an assistant professor in the Department of Mechanical Engineering at Turkish Naval Academy. He was born in Turkey in 1970. He graduated from the Mechanical Engineering in Turkish Naval Academy, in 1992. Dr. Girgin received his MSc degree from Naval Postgraduate School in USA in 1998, and Ph.D. degree in İstanbul Technical University in 2007. His general research interests are heat transfer, thermodynamics, thermal systems engineering, fluid mechanics, numerical methods.

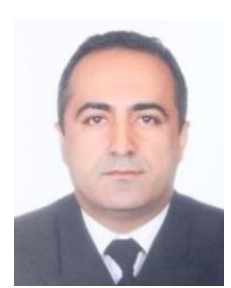

Cuneyt Ezgi is an associate professor in the Department of Mechanical Engineering at Turkish Naval Academy. He was born in Turkey in 1970. He graduated from the Mechanical Engineering in Gazi University in 1991. Dr. Ezgi received his MSc and Ph.D. degrees in the Department of Mechanical Engineering in Ege University in 2004 and 2009 respectively. His general research interests are heat transfer, thermodynamics, thermal systems engineering, heat exchangers, heat pumps, renewable energy technologies, fuel cells. 